\title{
Research On the "Cooperative Education” Model Cultivating In Higher Vocational Education
}

\author{
Lina $\mathrm{Yu}$ \\ Jiangxi Science and Technology Normal University Nanchang, China
}

\begin{abstract}
At present, there are many problems with the cooperative education model in China. Some of these are external environment, and there are also some problems in the process of cooperation, which requires common solutions among government, industry, schools and businesses. To ensure the cooperative education develops effectively, the successful experiences of foreign countries should be adopted to establish a protection mechanism and explore specific measures to ensure both school and enterprise benefit from it.

This paper firstly defines the concept of cooperative education model. Secondly, it reports on the different policies implemented in western countries, and then thirdly proposes the principles and basic framework of building cooperative education. Finally some measures are proposed to address the present problem of cooperative education model. The study substantiated the meaning of cooperative education model, and suggested that China needs to seek its own development path for cooperative education.
\end{abstract}

Index Terms: Cooperative Education; Vocational Education; Dual system; Industry-leading

(C) 2012 Published by MECS Publisher. Selection and/or peer review under responsibility of the International Conference on E-Business System and Education Technology

\section{Introduction}

This report is primarily concerned with research on the "Cooperative Education" model and how it is used to teach computer studies in higher vocational education. The work reviews the key policies and effective measures used in three countries-Germany, Australia and USA. Cooperative Education is known as: Dual Educational System in Germany and Industry-leading Model in Australia. However, this report uses the name of Cooperative Education, which is known as the model of USA.

What is cooperative education? Cooperative education has been defined as '... a structured educational strategy integrating classroom studies with learning, through productive work experiences in a field related to a student's academic or career goals'[1] .

In recent years, with the development of higher education (HE) in China has achieved a historic leap forward, especially with the rapid growth of higher vocational colleges. In the IT industry, the average annual growth rate is more than $30 \%$. Therefore, how IT professionals can be trained to meet the needs of the market, especially the shortage of skilled workers in computer science, is a priority for higher vocational education. HE in China faces Corresponding author:

E-mail address: angelfish1108@163.com 
severe challenges, as increasingly the traditional school training and classroom-centered models of vocational education have produced many problems.

An education system's reform can hardly do without policies from Government. If there is no policy to support the change, only minor improvements can be achieved by the teachers' change in teaching methods. Cooperative education also needs the support of the Government and enterprises.

\section{Studies on "Dual System" model in Germany}

The vocational education system in German is known as the "Dual System". Graduates from all types of school can enter vocational training at 15 or 16 but they are legally obliged to continue with some form of school-based education until they are 18 years old. This necessity is the root of the term 'dual system', while the students accept vocational training at the company (usually privately owned), they can learn professional theory and general education courses in the vocational college. The so-called "Dual System" entails a deep and specialized training, which closely relates to its industrial structure of high-end manufacturing.

Practice-orientated specialization is completed by an extensive range of courses combining theory and practice together [2]. The overall goal of the "Dual System" is to provide the best possible education for young people. In addition, the Dual System can enable them familiar with future work and society during the process of receiving education. This partnership provides a practice-based model of vocational education, combining learning with schools throughout the entire process:

\subsection{Funding:}

Employers pay for $85 \%$ of total cost on German vocational education with the other 15\% from state government. Enterprises are willing to offer practical part of vocational education, and some companies build training workshops. Large enterprises have built their own training centers or had their own vocational schools (such as Siemens, Volkswagen, IBM etc.) [3].

\subsection{Admission}

Upon entering vocational schools, students must first sign a contract with the enterprise as a "quasi-employee" status to accept vocational education. After signing a contract with the company, they can enjoy the company economic subsidies 500 to 1000 Euros per month. In some states, vocational schools need to charge tuition fees, but $90 \%$ of the cost is paid for by the enterprise.

\subsection{Teachers}

Full-time teachers, engineers and technicians from the enterprises and managers compose the teachers of vocational education. Practice-orientated specialization is completed by an extensive range of courses in theory and practice, and by the use of teaching technologies including modern multi-media technologies. Many teachers are industry-based professionals, who bring industry expertise into the classroom [2]. The number of part-time specialist teachers is more than full-time teachers. Teaching, especially the professional classes and practical courses were mainly undertaken by part-time teachers. Apart from a small number of part-time teachers which come from other universities, most of them are from enterprises. They not only have solid professional knowledge, rich experience, but can also bring the latest company production, operating, management and technological improvements into the schools.

\subsection{Student Employment}

A great emphasis is placed on cultivating specific and practical students in Germany vocational education; graduates must not only have a solid theoretical knowledge but also practical ability. They have demonstrated

Sponsors : < Exploration and Practice on Work-integrated training Mode Cultivating in Higher Vocational Education of Computer Engineering >--2009 Teaching Reform Projects of Jiangxi Province

Project NO: JXJG-09-13-3 
competence to accomplish the jobs quickly and be familiar with enterprises' production management. So the students can adapt and qualify the work of enterprise. Thus, the employment of students in German vocational education training is high.

\section{Research on "Industry-leading" model of Australia}

Currently, under the framework of national training, Australia has formed flexible TAFE ('Technical and Further Education' for short, is Australia's largest post-compulsory education and training organizations) mode and vocational complete system of education and training, which converged primary, secondary and higher education [4]. During the past years' reform of vocational education, Australia has formed the industry-leading vocational education system that enables TAFE to have a great impetus on sustainable development. Industry in the role of TAFE is very prominent, mainly reflected in:

\section{1 Industry leads macro decision-making of vocational education and training.}

In the Report of the Australian Education Council Review Committee $<$ Young People's Participation in Postcompulsory Education and Training>, it emphasized that national and state management organizations of TAFE are mainly composed of personnel from and on behalf of the industry will. Other important institutions, such as industry training advisory committee of federal and state TAFE, make the macro decision on the major issues of TAFE development (such as adapting the job market, meeting the business needs and seeking funds, etc.) by these institutions reflects their leading role in the industry.

\section{2 Industry participates in the whole process of TAFE Colleges.}

Industry's leading role is also reflected the whole process of TAFE colleges, specifically in the following three aspects.

1) Industry participates in school management and formulates educational specifications. All TAFE colleges have a board [5]; the President and most members are the senior enterprise industry experts who are full of experience. The Board usually meets once every quarter of the year, doing research and making decisions on the scale of education, infrastructure projects, product development, personnel arrangements and funding. In addition, enterprises staffs take part in determining a new staff recruitment process.

2) Industry can enrich teachers for TAFE. The industry uses the latest technology to influence teaching in schools by encouraging part-time teachers to give lecture to schools. Industry personnel are proud of being part-time teachers in college. Part-time teachers usually work in the evenings [6]. High-level experts in the industry accept the invitation of Institute for regular or irregular technical presentations. According to the management regulars of TAFE Institute, the enterprises receive two weeks of each academic year for teaching staff working in enterprises, and absorb the teachers become members of associations [7]. Thus it makes sure that college teachers are not divorced from the actual.

3) Industry supports construction of training base. Industry participates in school teaching through construction of training base, accepting students in internships and other practical way. To train new employees who master advanced technology, the most advanced production equipment available to the Institute is used to strengthen the construction of internal training practical bases. Furthermore, industry is responsible for constantly updating them. In addition, the enterprises also support schools to establish a nationwide simulation training company network for all TAFE College to use. 


\section{3 Industry invests in job skills training}

Australian Government requires companies to produce the equivalent of $2 \%$ of payroll for training (in fact, businesses have generally exceeded this ratio) through legislation [7]. Entrepreneurs are aware that only relying on scientific progress and improving the quality of employees, enterprises can succeed in the intense competition of the market.

\section{Research on "Cooperative Education" model of USA}

The cooperative education in United States is school-based and enterprise-supplemented. The main body of vocational education in United States is the community college. "Cooperative education" is throughout the entire process of community colleges:

\section{1 Management system}

The State Government has higher education commission and the commissions of community college, the members are appointed by governor. There are about 10 people in each community who are come from education, industry and commerce [4].

\section{2 Sources of funds}

$50 \%$ of Community College funding is mainly from tax revenue of the community, about $25 \%$ from state government, student fees accounted for about 25\%." Different states have different way to allocate funding; one kind is that the state and community invest respectively, another is Community turned over the tax first, and then the State Government allocates to Institute.

\section{3 Students}

There are a wide range of community college students, the age span is from 15 to 70, the average age is 30year-old: significant differences between educational background [4].

\section{4 Teachers}

Schools rely on part-time teachers to get many information of community demand. In addition, it enhances the target of services, at the same time, reducing operating costs.

\section{The Models of Cooperative Education}

In the western countries, cooperative education can be divided into two types: one is the German "Dual System" as the representative to enterprise-based learning; another educational system is represented by the United States, school-based learning.

Although different countries have different co-education models, schools and enterprises divide the work and cooperate in cultural knowledge and skills training. Cooperative education shows the combination of theory and practice, and the advantages of sharing resources between enterprises and schools. Governments attach great importance to its development; they passed legislation to strengthen integration of engineering interventions. In addition to laws, administrative measures and macroeconomic management [5], many governments provide funding support. Industries also play a vital role not only in school management, educational standards; they are also responsible for teaching quality assessment. The involvement of government and industry enables cooperative education to integrate. 


\section{How to learn from foreign experience?}

Combined with China's specific conditions, which training mode to choose to implement is a serious problem we face. To solve this problem, first of all, we need to compare our personnel-training model with other countries'.

Compared with western countries, support system for personnel-training mode in China needs improvement. In the level of education, we lack management system, personnel structure, curriculum system and other aspects of support.

First of all, most schools do not yet have a specialized management department. Forces of management are relatively weak, managed by teaching management department instead. The teaching management department set the main targets. It is difficult for schools to be competent for substantial external liaison and process management.

Regarding the staff structure, there are no specialized administrative agencies. It is difficult to have the management team to cultivate the teachers.

In the teaching system, we still not have mature "full credit" and "flexible education system", so the students have certain restrictions to choose subjects.

In the curriculum aspect, we regard courses from teaching standpoint not from the educational standpoint. Therefore, we do not totally put outside work as a required course. Although the occupation certificates have been put into the course system, we have not integrated their contents with the knowledge. Furthermore, most of the curriculum emphasizes knowledge, but not work-related curriculum design and content.

Low cooperation initiative of enterprises is a major obstacle. The government did not invest special funds to encourage schools to implement training mode, so schools' enthusiasm and initiative are not enough.

In terms of adapting to the environment, since this training mode is directly related to the labor market, so the imbalance of local economic development is the difficulty for different areas to implement cooperative education.

From other countries' experience, we can make several improvements:

\section{1) Every party's rights and obligations in cooperative education should be clearly defined.}

In the process of implementing cooperative education, colleges and enterprises in western countries all assume a clear obligation, and have the necessary rights. Moreover, they specifically stated students' obligations and rights in the cooperative education. Table 1 has been designed to show implementation and function of cooperative education.

TABLE I. IMPLEMENTATION AND FUNCTION OF COOPERATIVE EDUCATION

\begin{tabular}{|c|c|c|c|c|}
\hline Subject & Enterprises & Schools & Teachers & Students \\
\hline Function & $\begin{array}{c}\text { Teaching } \\
\text { goals }\end{array}$ & Organization & Implementation & Effect \\
\hline
\end{tabular}

Schools' obligations are: to actively offer professional and curriculum the company needed; selecting students who have certain skills and good working attitude to the company to complete work term; and establish efficient implementation institutions of cooperative education (Report of the Australian Education Council Review Committee: 1991). The benefits they can enjoy include: companies providing professional materials and funding that the school required, and expanding the school's reputation and student employment.

Enterprise' obligations are: according to the changes of demands in market, provide specific teaching goals for school, to send the staff who have enthusiasm in cooperative education to manage students, providing information for students, assessing students' performance, and participating in the formulation, modification, implementation of the Cooperative Education Program [5]. The benefits they can enjoy include: addressing human needs of the temporary work supporting, identifying the fixed competence employees and proposing which curriculum or specialty needs to be developed and so on. 
Student obligations include good cooperation with the company, hard work and submitting work report on time. In addition to work experience, the students also enjoy the rights and interests, such as, deepening their understanding of the contents from the classes [8]. They may also choose the workplace related to their specialty and get appropriate remuneration for work.

\section{2) Cooperative education needs a good social atmosphere.}

Government's attention and leaders' speech have a positive impact to public opinion. An important reason why developed countries and regions in the world have made great progress on vocational education is the attention and support. As the students who are cultivated by cooperative education have high ability [8], and have a good income, corresponding also have a higher social status. People have great respect for vocational education and training; they do not think that such education model is inferior. Some foreign students after graduation are targeted to enter vocational schools to learn skills, so as to better meet the manpower needs of the market.

\section{3) Cooperative education training model in China should have two functions.}

First, we should improve students' professionalism; second, we should lead the professional development of teachers in curriculum reform and construction. The former is mainly realized in campus, because the main objects are students. Only in a real work environment, students' professionalism can be cultivated. The latter can be realized on campus and off campus, and mainly on campus. Although the professional construction must combine with the employer, the main objects are teachers. Therefore, in the three major structural elements: schools, students and employers, and schools' teachers are essential. In terms of responsibility, teachers have to participate in the management of the students, and also chair the professional development. So mobilizing the enthusiasm of teachers is the key.

\section{CONCLUSION}

In conclusion, this study highlighted the importance of implementing cooperative education in China, and analyzed the different policies and methods applied in different countries. We can use the experiences of other countries for reference and bring them to China. In this section, three important things that I have learnt will be stated.

The key thing that I have learnt was that different policies and models that are relevant to cooperative education exist in Germany, Australia and the USA by reading a lot of references and government reports.

Secondly, the qualitative research encouraged me to examine which mode can be applied in China. Throughout the successful experiences of cooperative education, the essence of everything is starting from the national conditions to find the best point of integration between enterprise and school and the formation of their special characteristics. We should deepen the close cooperation with enterprises and employ technical personnel of enterprises involved in the reform of teaching and curriculum development.

Thirdly, as a teacher who was involved in this study, I also analyze how to lead the professional development of teachers in curriculum reform and construction. Teachers can participate in the enterprise project to gain the experience in project development, and understand the practical knowledge required in the project development process. 


\section{References:}

[1] ANTJE COCKRILL \& PETER SCOTT (1997), Vocational Education and Training in Germany: trends and issues, Journal of Vocational Education and Training, Vol. 49, No. 3, 1997

[2] Axel Göhringer (2002), University of Cooperative Education - Karlsruhe: The Dual System of Higher Education in Germany, Asia-Pacific Journal of Cooperative Education

[3] Hildegard Brauns and Susanne Steinmann (1997), Educational Reform in France, West-Germany, the United Kingdom and Hungary: Updating the CASMIN Educational Classification, Arbeitsbereich I / Nr. 21 Mannheim 1997

[4] Patricia L. Linn, Adam Howard, Eric Miller(2003), Handbook for Research in Cooperative Education and Internships, Routledge (19-83)

[5] ERICA SMITH (2004), Vocational Education and Training in Schools in Australia: what are the consequences of moving from margins to mainstream? Journal of Vocational Education and Training, Volume 56, Number 4, 2004

[6] PETER J. SMITH (2001), Learners and Their Workplaces: towards a strategic model of flexible delivery of training in the workplace, Journal of Vocational Education and Training, Volume 53, Number 4, 2001

[7] Young People's Participation In Post-compulsory Education and Training (1991), Report of the Australian Education Council Review Committee

[8] ROGER HARRIS, PETER WILLIS, MICHELE SIMONS \& EMILY COLLINS (2001), The Relative Contributions of Institutional and Workplace Learning Environments: an analysis of apprenticeship training, Journal of Vocational Education and Training, Volume 53, Number 2, 2001 